\title{
PELATIHAN PENGOLAHAN VIRGIN COCONUT OIL (VCO) SEBAGAI MINUMAN SUPLEMEN PADA MASA PENDEMI COVID 19 DI DESA WUNGA
}

\author{
Marselinus Hambakodu'1), Alfons Hina Tarapanjang ${ }^{1)}$, Elvis Pati Ranja ${ }^{1)}$, Merry Christine Nara1) \\ 1)Fakultas Sains dan Teknologi, Universitas Kristen Wira Wacana Sumba, NTT, Indonesia \\ Corresponding author: Marselinus Hambakodu \\ E-mail : marsel.hambakodu@unkriswina.ac.id
}

Diterima 11 Agustus 2020, Direvisi 20 September 2020, Disetujui 21 September 2020

\begin{abstract}
ABSTRAK
Kelapa merupakan tanaman perkebunan yang dapat tumbuh pada daerah tropis, dan selama ini masyarakat Desa Wunga masih mengolah buah kelapa menjadi minyak goreng. Penganekaragaman pengolahan buah kelapa perlu adanya inovasi baru dalam pengolahan buah kelapa tanpa menggunakan panas yang dilakukan secara alami. Kegiatan ini bertujuan untuk meningkatkan ketrampilan warga dalam mengolah kelapa menjadi pangan fungsional sebagai minuman suplemen dalam menghadi pandemi Covid 19. Metode yang digunakan mulai dari perencanaan, pengolahan dan pelatihan. Hasil pelaksanaan adalah (1). Adanya peningkatan ketrampilan yang diperoleh warga Desa Wunga terkait pengolahan kelapa menjadi minyak kelapa murni; tanggapan kesesuaian materi dengan tujuan pelatihan $55,6 \%$ baik, kesesuaian dengan kebutuhan $55,6 \%$ baik, kualitas materi $50 \%$ baik, penyampaian materi $50 \%$ baik, sistematika dan alur materi $55,6 \%$ baik, partisipatif dan kedekatan dengan peserta $55,6 \%$ baik, dan tanggapan organoleptik $60-66 \%$ sangat suka. (2)Dari tujuh indikator tanggapan yang didapatkan, terlihat bahwa secara umum para peserta memberikan tanggapan positif dan menganggap bahwa kegiatan ini sangat bermanfaat bagi mereka dalam menghadapi pandemi Covid 19 serta organoleptik VCO. Indikator organoleptik VCO terdiri dari warna, aroma dan rasa memberikan tanggapan sangat suka.
\end{abstract}

Kata kunci: desa Wunga; pelatihan; pengolahan; virgin coconut oil.

\begin{abstract}
Coconut is a plantation crop that can grow in tropical areas, and so far the people of Wunga Village are still processing coconuts into cooking oil. Diversification of coconut fruit processing requires new innovations in coconut fruit processing without using heat which is done naturally. This activity aims to improve the skills of residents in processing coconut into functional food as a supplement drink in fighting the Covid 19 pandemic. The methods used range from planning, processing and training. The results of the implementation are (1). An increase in the skills acquired villager related Wunga oil processing into pure coconut oil; responses of material suitability with training objectives $55.6 \%$ good, conformity to needs $55.6 \%$ good, $50 \%$ good quality of material, $50 \%$ good material delivery, $55.6 \%$ good systematic and flow of material, participatory and closeness to participants $55,6 \%$ was good, and $60-66 \%$ organoleptic responses were very favorable. (2). Of the seven indicators obtained responses, it appears that in general the participants responded positively and considers that this activity is very beneficial for them in the face of a pandemic Covid 19 and organoleptic VCO. VCO organoleptic indicators consisting of color, aroma and taste gave very favorable responses.
\end{abstract}

Keywords: wunga village; processing; virgin coconut oil.

\section{PENDAHULUAN}

Pohon kelapa (Cocos nucifera) merupakan tanaman perkebunan yang banyak tersebar di wilayah tropis, termasuk Desa Wunga Keacamatan Haharu Kabupaten Sumba Timur. Minyak kelapa yang diproduksi di Sumba Timur umumnya merupakan minyak kelapa yang diolah secara tradisional yang dibuat dengan metode pemanasana atau dimasak, dimana sifat fisik yang kurang baik. Proses pemanasan minyak kelapa diatas $100^{\circ} \mathrm{C}$ pada proses refining yang menyebabkan perubahan secara oragnoleptik, fisik, dan kimia terutama dari asam lemak tak jenuh serta merusak antioksidan alami yang ada pada kelapa. Data Badan Pusat Statistik Sumba Timur 2019 melaporkan bahwa luas tanaman perkebunan kelapa seluas $4.301 \mathrm{Ha}$, produksi kelapa 1.375 ton, produktivitas 692 ton/Ha. Produksi kelapa selama tahun 2017 - 2018 sebesar 1.367 ton (BPS Sumba Timur, 2019). Berdasarkan data diatas pengolahan kelapa menjadi produk 
pangan masih minim, sehingga potensi ini menjadi peluang bagi masyarakat untuk mengolah menjadi produk pangan.

$$
\text { Pengolahan pangan tentang }
$$

pengolahan minyak kelapa murni dapat meningkatkan nilai tambah serta fungsinya yang sangat esensial untuk kesehatan masyarakat. Salah satu pengolahan pangan yang dikembangkan saat ini adalah pengolahan virgin coconut oil. Manfaat virgin coconut oil bagi kesehatan manusia yakni meningkatkan imuntas tubuh, menyembuhkan beberapa penyakit yang disebabkan oleh bakteri, virus dan jamur (Madhavan et al., 2010; Verma et al., 2020). VCO dikenal sebagai minuman suplemen yang berfungsi sebagai anti bakteri, anti stress dan anti kanker (Yeap et al., 2015). Virgin coconut oil juga mengandung antioksidan seperti fenol, dan vitamin $\mathrm{E}$ yaitu tocoferol dan tocotrienol yang sangat baik untuk mendukung kesehatan manusia (Dumacans et al., 2016).

Teknologi yang sudah ada untuk menghasilkan minyak kelapa murni diantaranya adalah teknologi perubahan bentuk emulsi, teknologi pemanasan langsung, teknologi fermentasi, dan teknologi enzimatis. Beberapa metode yang digunakan seperti penambahan asam asetat dengan waktu pengadukan berbeda (Aprilasani dan Adiwarna, 2014), penambahan $\mathrm{NaCl}$, garam $\mathrm{Na}_{2} \mathrm{SO}_{4}$ serta pengeringan dengan oven untuk mengurangi kadar air minyak kelapa murni (Raharja dan Dwiyuni, 2008), pembuatan minyak kelapa murni dengan penembahan enzim bromelain (Prayitno, 2019). Secara umum permasalan Desa Wunga adalah belum memaksimalkan sumber daya alam yang ada yakni potensi kelapa yang cukup melimpah. Petani belum mampu mengolah kelapa menjadi bahan pangan fungsional yang bermanfaat untuk mendukung peningkatan ekonomi.

\section{HASIL DAN PEMBAHASAN \\ Pelaksanaan Metode Pembuatan VCO}

Adapun tahapan-tahapan yang dilakukan yakni tahap persiapan: observasi awal dengan pemetaan masalah dan pemetaan potensi Desa. Tahap pelaksanaan: pada tahap sosialisasi ini tim PKM menjelaskan tujuan dan maksud kegiatan pelatihan. Tahap pelatihan; materi pelatihan sudah dicantumkan secara lengkap pada buku panduan pengolahan VCO, pelatihan di lakukan di kantor Desa Wunga.

Adapun tahapan pembuatan virgin coconut oil sebagai berikut;

1. Tahap Pertama: Pembuatan Santan

Buah kelapa tua varietas Dalam (berumur 11-12 bulan) dipilih sebanyak 20 buah, dikeluarkan sabut dan tempurung. Kemudian testanya dikeluarkan dengan pisau atau parang agar tidak mempengaruhi warna santan. Daging buah kelapa yang sudah dibuang batoknya kemudian diparut. Diambil santannya kemudian ditambah air panas $\left(70^{\circ} \mathrm{C}\right)$ dengan perbandingan $2: 1$, diperas dan disaring. Masukkan di dalam toples besar, setelah itu diamkan selama 23 jam, sampai terpisah menjadi dua bagian (krim dan skim).

2. Tahap Kedua: Proses Fermentasi

Tahap fermentasi bertujuan untuk mendapatkan minyak yang murni dalam toples besar yang dilakukan secara anaerob atau tanpa udara. Pada tahap fermentasi harus dilakukan secara berhati-hati, yakni memperhatikan posisi toples supaya jangan miring, tidak mudah goyang ketika disentuh saat kerja, tidak masuk udara, tidak masuk debu dan bebas bakteri. Waku fermentasi dilakukan selama 24 jam.

3. Tahap Ketiga: Pemisahan dan Penyaringan Pemisahan dan penyaringan VCO dilakukan setelah melewati tahap fermentasi. Hasil akhir dari fermentasi adalah minyak VCO dan blondo. Minyak VCO dipisahkan dari blondo dengan cara mengambil minyak dengan menggunakan sendok kuah atau bisa juga menggunakan selang kecil. Minyak tersebut ditampung dalam wadah yang steril. Proses penyaringan dilakukan dengan cara menyaring minyak VCO dengan menggunakan saringan yang dilapisi tissue kering. Penyaringan minyak VCO dilakukan sebanyak 5 kali.

4. Tahap Keempat: Packing dan Labeling Minyak VCO yang telah disaring dimasukkan kedalam botol plastik yang sudah disteril untuk dipacking. VCO yang telah dipacking pada botol disteril dengan cara menyiram air hangat pada bagian luarnya, kemudian dilap sampai kering. Botol VCO diberi label produk.

\section{Pelatihan dan Tanggapan Peserta}

Berdasarkan hasil observasi yang dilakukan sebelum pelaksanaan kegiatan, terdapat masalah terkait pengolahan kelapa yaitu pemahaman pemanfaatan kelapa dan hasil olahannya dan belum adanya pemhaman tentang strategi meningkatkan imunitas tubuh di masa pandemi covid 19. Kegiatan PKM dilaksanakan dengan memperhatikan protokol kesehatan dan anjuran pemerintah tentang pencegahan Corona Virus Desease (Covid) 19. Kelapa yang selama ini diolah adalah minyak kelapa yang dibuat minyak untuk keperluan masak dan kelapa biasanya dijual mentah di pasar. Padahal, ada banyak pengolahan yang berbahan dasar kelapa yang dapat dijadikan minuman maupun makanan yang kaya nutrisi, 
baik untuk dikonsumsi sendiri maupun dijual. Penyelesaian solusi dibuat dalam satu tahapan yakni pelatihan pembuatan minyak kelapa murni. Jumlah peserta yang mengikuti kegiatan 20 orang yang didominasi perempuan (ibu rumah tangga). Para peserta tersebut sangat antusias mengikuti demonstrasi pengolahan minyak kelapa murni.

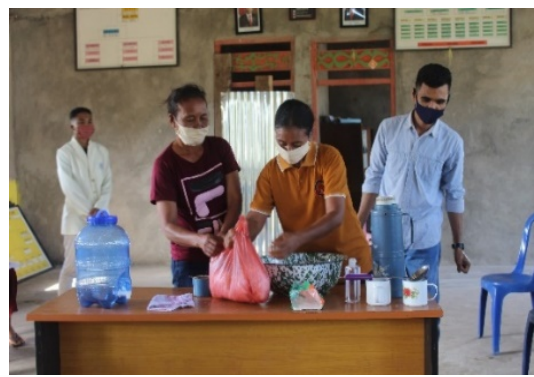

Gambar 1. Tim PKM mendemonstrasi pengolahan minyak kelapa murni.

Pada pelatihan ini para peserta juga diberikan kesempatan untuk membuat sendiri minyak kelapa murni setelah melihat pemaparan materi yang dilakukan oleh tim PKM. Ada beberapa materi yang diberikan yakni mutu dan nutrisi VCO, kegunaan VCO bagi kesehatan, dan teknik pembuatan VCO. Materi pelatihan digabungkan dalam bentuk buku panduan dan telah dibagikan kepada seluruh peserta pelatihan dan produk VCO hasil kerja tim PKM didemonstrasikan dan diminum oleh semua peserta. Produk VCO tersebut dilakukan pengujian organoleptik terdiri dari warna, aroma dan rasa.

Kegiatan ini dimulai dengan sambutan dari pihak Desa Wunga oleh Kepala Desa, lalu dilanjutkan dengan sambutan dari pihak kampus Universitas Kristen Wira Wacana Sumba oleh dosen Prodi Peternakan. Sesi penyampaian materi VCO dan sekaligus demonstrasi pengolahan VCO dan uji organoleptik produk VCO hasil tim PKM. Pemateri menjelaskan bahwa minyak kelapa murni atau yang disebut virgin coconut oil (VCO) memiliki kandungan nutrisi yang tinggi terutama kandungan asam laurat yang dapat meningkatkan imunitas tubuh. Selain itu juga, berdasarkan literatur jurnal VCO dapat menyembuhkan beberapa penyakit yang disebabkan oleh virus, bakteri dan jamur.

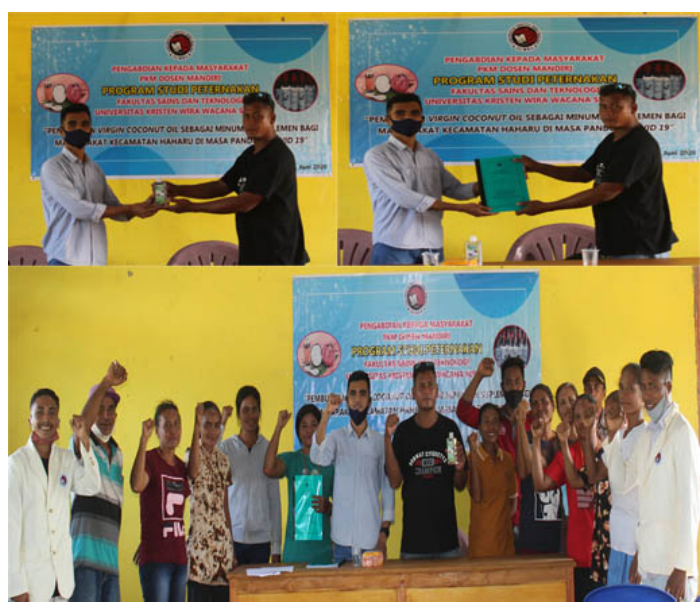

Gambar 2. Tim PKM memberikan buku panduan dan VCO

Dalam masa pandemi Covid 19 ini, VCO dapat dijadikan salah satu alternatif produk pangan yang diminum untuk meingkatkan imunitas tubuh. Dijelaskan bahwa pengolahan VCO sangat mudah, namun perlu dijaga kebersihan alat dan orang yang mengerjakannya sehingga pengolahan VCO berhasil.

Pada akhir kegiatan PKM dilakukan pose bersama antara tim PKM dan masyarakat Desa Wunga sebagai dokumen kampus. Buku panduan berisi tentang potensi kealapa, mutu dan nutrisi VCO, kegunaan VCO bagi kesehatan, teknik pembuatan VCO dan penutup. Produk VCO yang dibagikan merupakan hasil kerja dari tim PKM sebelum melakukan pelatihan (Gambar 3).

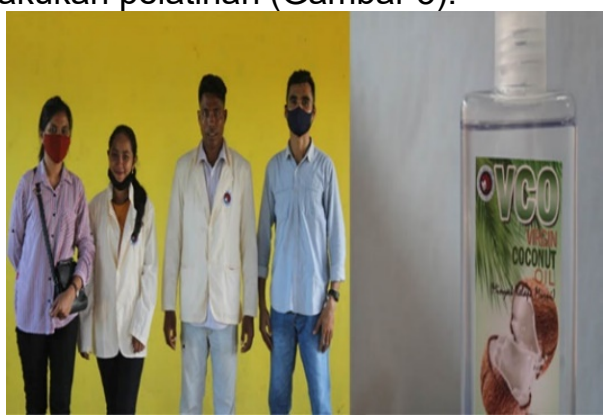

Gambar 3. Produk Virgin Coconut Oil (VCO) dan Tim PKM

Setelah sesi pemberian materi selesai, para peserta diminta untuk memberikan tanggapan tentang pelaksanaan kegiatan ini yang meliputi beberapa indikator penilaian seperti kesesuaian dengan tujuan pelatihan, kesesuaian dengan kebutuhan, kualitas materi, cara penyampaian, sistematika alur materi, tingkat pastisipatif, kedekatan dengan peserta, dan organoleptik produk VCO tim PKM.

1. Kesesuaian materi dengan tujuan pelatihan Indikator kesesuaian materi dengan tujuan merupakan poin pertama yang dinilai. Tujuan pelatihan telah disampaikan terlebih 
dahulu sebelum sesi awal pelatihan VCO. Tujuan pelatihan adalah untuk untuk memberikan pelatihan tentang pengolahan minyak kelapa murni sebagai minuman suplemen yang lebih bernilai baik dikonsumsi sendiri maupun dikomersialkan di masa pandemi covid 19 di Desa Wunga.

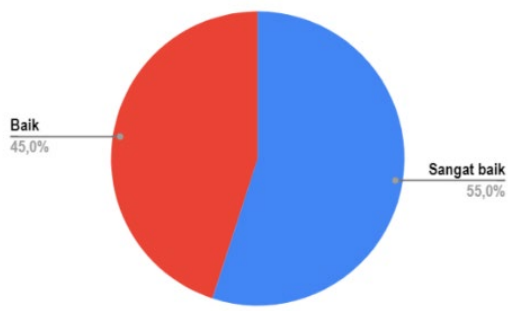

Gambar 4. Persentase tanggapan kesesuaian materi dengan tujuan

Berdasarkan tanggapan yang diberikan pada gambar 4, terlihat bahwa peserta memberikan tanggapan materi yang diberikan sesuai dengan tujuan pelatihan yakni $38,9 \%$ sangat baik dan baik $55,6 \%$ dan sisanya menilai cukup baik.

2. Kesesuaian dengan kebutuhan

Indikator ini, peserta diminta untuk memberikan tanggapan tentang materi yang diberikan tentang kesesuaian materi dengan kebutuhan peserta pelatihan.

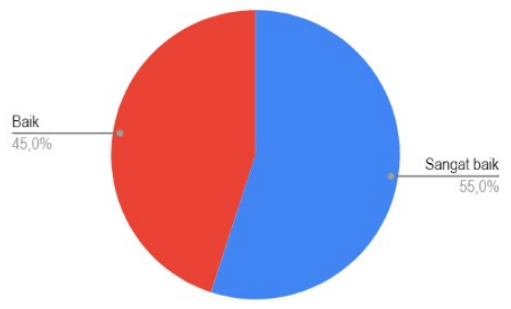

Gambar 5. Persentase tanggapan kesesuaian dengan kebutuhan

Berdasarkan hasil rekapan tanggapan peserta pelatihan VCO di Desa Wunga memiliki anggapan bahwa materi yang diberikan $55,6 \%$ baik, $38,9 \%$ sangat baik dan sisanya $5,6 \%$ cukup baik.

3. Kualitas materi

Peserta pelatihan VCO memberikan tanggapan tentang kualitas materi yang diberikan yakni $38,9 \%$ sangat baik, $50 \%$ baik dan sisanya $11,1 \%$ cukup baik.

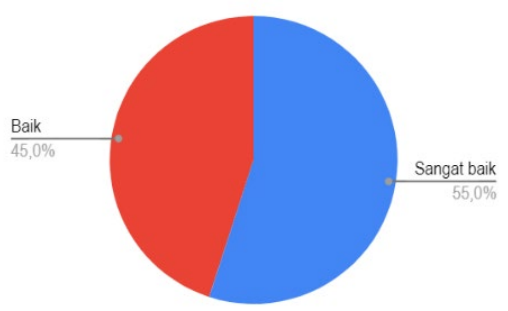

Gambar 6. Persentase tanggapan kualitas materi

Penyampaian materi yang disampaikan oleh tim PKM sangat membantu peserta untuk lebih mudah memahami seperti penggunaan bahasa lokal masyarakat setempat. Materi yang disampaikan tercantum dalam buku panduan pengolahan VCO dan dijelaskan setiap bab menggunakan bahasa Indonesia dan bahasa daerah masyarakat Sumba Timur.

4. Cara penyampaian materi

Materi yang disampaikan oleh tim PKM kepada peserta berjalan dengan baik karena dalam penyampaian materi menggunakan contoh-contoh sederhana yang ada disekitar masyarakat dan penggunaan bahasa daerah.

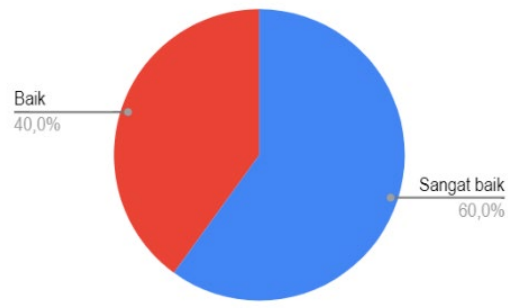

Gambar 7. Persentase tanggapan

cara penyampaian materi

Berdasarkan hasil analisis, peserta pelatihan memberikan tanggapan cara penyampaian materi oleh tim PKM yakni 38.9\% sangat baik, $50 \%$ baik dan sisanya $11,1 \%$ cukup baik.

5. Sistematika dan alur materi

Materi dan alur pelatihan yang disampaikan baik sangat baik $33,3 \%$ dan $55,6 \%$ baik serta sisanya $11,1 \%$ cukup baik. Sistematika materi yang disampaikan yakni menggali potensi pohon kelapa dan kelapa yang ada di Desa Wunga, memberikan pemahaman tentang manfaat kelapa dan produk olahan lainnya, memberikan informasi tentang tahapan pembuatan minyak kelapa murni.

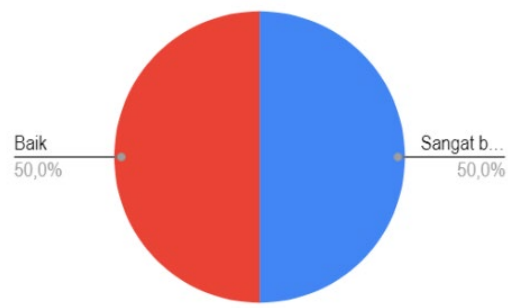


Gambar 8. Persentase tanggapan sistematika dan alur materi

6. Tingkat partisipatif dan kedekatan dengan peserta

Tanggapan peserta tentang tingkat partisipatif yakni $55,6 \%$ baik, $33,3 \%$ sangat baik dan $11,11 \%$ cukup, sedangkan kedekatan dengan peserta $33,3 \%$ sangat baik, $50 \%$ baik dan $16.7 \%$ cukup baik. Tingkat partisipatif dan kedekatan dengan peserta merupakan faktor pendukung agar pelatihan dapat berjalan dengan efektif (Fajriani dan Fidyansari, 2019).

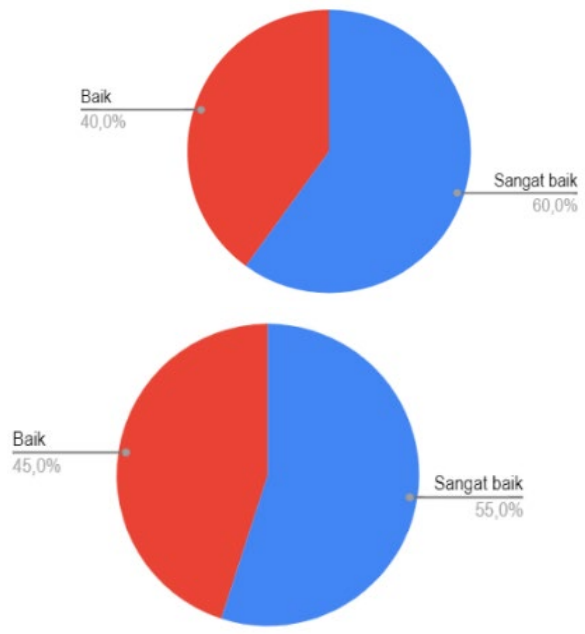

Gambar 9. Persentase tanggapan tingkat partisipatif dan kedekatan

\section{Organoleptik VCO}

Penilaian organoleptik VCO yakni warna, aroma dan bau. Berdasarkan hasil analisis persentase tanggapan warna $60 \%$ sangat suka dan $40 \%$ suka. Produk VCO berwarna putih jernih atau tudak berwarna, hal ini mengindikasikan bahwa VCO tersebut berkualitas baik karena telah memenuhi syarat Badan Standar Nasional SNI 73812008.
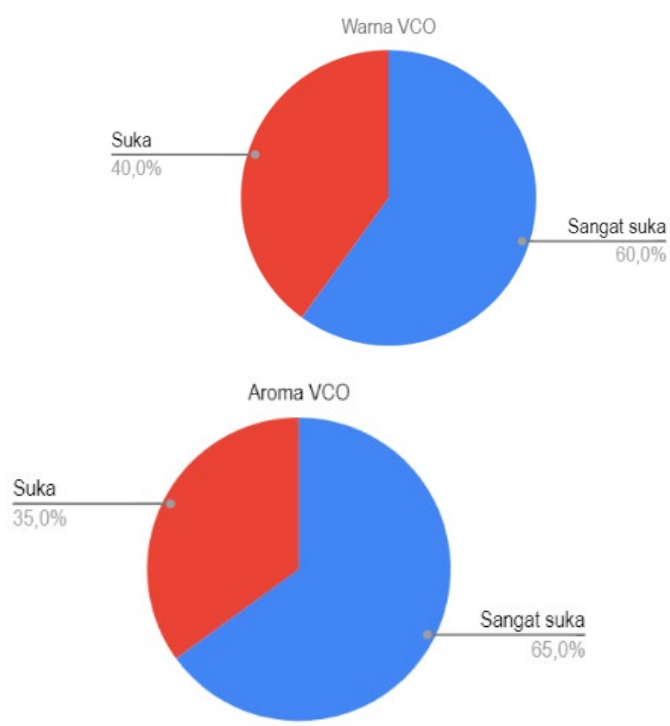

Gambar 10. Persenrtase tanggapan warna dan aroma VCO

Gambar 10 diatas, produk VCO memiliki aroma khas kelapa segar dan hasil tanggapan peserta yakni $65 \%$ sangat suka dengan aroma VCO. Berdasarkan hasil analisis diatas, mengindikasikan bahwa VCO berkualitas baik karena telah memenuhi syarat mutu Badan Standar Nasional SNI 73812008.

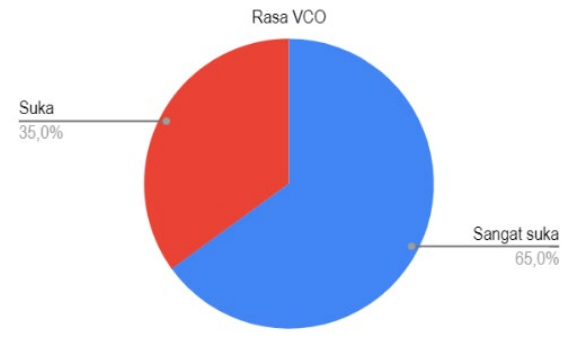

Gambar 11. Persentase tanggapan rasa VCO

Pada gambar 11 diatas, tanggapan peserta tentang rasa VCO $66 \%$ sangat suka dan $35 \%$ suka. Rasa VCO normal dan khas minyal kelapa, sehingga berdasarkan Badan Standar Nasional SNI 73812008 telah memenuhi syarat mutu.

\section{SIMPULAN DAN SARAN}

Berdasarkan hasil dan pembahasan dapat disimpulkan bahwa pelaksanaan kegiatan PKM Program Studi Peternakan sebagai berikut; 1) indikator tanggapan kegiatan PKM terlihat bahwa secara umum peserta pelatihan pengolahan VCO di Desa Wunga memberikan tanggapan positif dan menganggap bahwa kegiatan ini sangat suka dan bermanfaat bagi mereka. 2) bedasarkan penilaian organoleptik produk VCO sangat suka yakni warna, aroma dan rasa memenuhi 
syarat mutu SNI 73812008.

\section{UCAPAN TERIMAKASIH}

Kami mengucapkan limpah terima kasih kepada kampus Universitas Kristen Wira Wacana Sumba yang telah mendanai kegiatan pengabdian kepada masyarakat (PKM) Dosen Mandiri Tahun 2020.

\section{DAFTAR RUJUKAN}

Aprilasani, Z., \& Adiwarna .(2014). Pengaruh Lama Waktu Pengadukan dengan Variasi Penambahan Asam Asetat dalam Pembuatan Virgin Coconut Oil (VCO) dari Buah Kelapa. Konversi, 3(1), pp. 1-12

Badan Standardisasi Nasional (2008) 'Minyak kelapa virgin (VCO)', Indonesia, pp. 128.

Bolung, Y. Y., Mamuaja, C(Bolung, Y. Y., Mamuaja, C. F., Mandey, L. C. (2013). Kajian Mutu Fisik dan Kimia Virgin Coconut Cooking Oil (VCCO) dari Beberapa Varietas Kelapa (Cocos nucifera L.). Cocos, 2(4): 1-9.

Badan Pusat Statistik. (2019) Sumba Timur Dalam Angka 2019. Badan Pusat Statistik.

Broudiscou, L. and Jouany, J. P. (1995) 'Reassessing the manipulation of protein synthesis by rumen microbes', Reproduction, Nutrition, Development, 35(5), pp. 517-535. doi: 10.1016/09265287(96)80218-8.

Fajriani, F. and Fidyansari, D. (2019) 'PKM Pengolahan Rumput Laut di Desa Wiringtasi Pinrang', MATAPPA: Jurnal Pengabdian Kepada Masyarakat, 2(2), p. 162.

doi: 10.31100/matappa.v2i2.451.

Prayitno, S. A. (2019). The Physical and Chemical Properties of Virgin Coconut Oil (VCO) Product Obtained Through Fermentation and Enzymatic. FOODSCITECH, 2 (1): 1 - 6.

Raharja, S. and Dwiyuni, M. (2008) 'Kajian Sifat Fisiko Kimia Ekstrak Minyak Kelapa Murni (Virgin Coconut Oil) Yang Dibuat Dengan Metode Pembekuan Krim Santan', Jurnal Teknik Industri Pertanian, 18(2), pp. 71-78.

Silaban, R. (2010) 'Pembuatan Virgin Coconut Oil (VCO) Melalui Kombinasi Teknik Fermentasi dan Enzimatis Menggunakan Ekstrak Nenas', Jurnal kimia, pp. 56-64.

Triton, J. and Mesu, R. R. (2018). 'PEMBUATAN VIRGIN COCONUT OIL ( VCO ) DENGAN MENGGUNAKAN ENZIM PAPAIN DI DESA GERBO

Yeap, S. K., Beh, B. K., Ali, N. M., Yusof, H. M., Ho, W. Y., Koh, S. P., Alitheen, N. B., and Long, K. (2015) 'Antistress and antioxidant effects of virgin coconut oil in vivo', Experimental and Therapeutic Medicine, 9(1), pp. 39-42. doi: 10.3892/etm.2014.2045. 